\title{
Authentic Leadership: A Historical Perspective
}

\author{
Milorad M. Novicevic \& Michael G. Harvey \\ University of Mississippi \\ M. Ronald Buckley-University of Oklahoma \\ Jo Ann Brown-Radford University \\ Randy Evans-University of Arkansas-Little Rock
}

The purpose of this paper is to interpret the historical meanings conveyed by Barnard's classic works and use them for theorizing about authenticity of leaders in executive roles. Our analysis employs an interpretative logic for meanings of historical ideas proposed by Bevir. As an outcome of this analysis, we identify the conditions that contribute to the failure, crisis, tragedy, and/or success of leader authenticity. In addition, we discuss practical and research implications of the proposed framework.

Oftentimes when considering ideas we believe to be novel, we see that they have, in many instances, already received considerable discourse from scholars who have preceded us. Although the nomenclature changes, the gist of the ideas is frequently quite similar. Looking back at the meanings underlying these ideas will provide a more firm theoretical foundation for these "novel" concepts. Instead of starting from a blank slate, we can use these reflective thoughts as a spring board to a more thorough understanding of concepts of interest.

The concept of authenticity (i.e., the idea of 'being oneself' or being 'true to oneself') is becoming a central focus of responsible behavior of leaders in post-Enron era. While in ancient Greece authenticity was ascribed only to leaders who "posited themselves" (Ferrara, 1998: 15), leader authenticity is described today more broadly as leader resolve to take responsibility for personal freedom and organizational and communal obligations so that leaders could make choices that would help them construct their selves as a moral individuals. In management and organization studies, this authentic capacity of a leader to balance responsibilities for private freedom and public obligation was first devised as the litmus test of executive quality by Chester Barnard (1938). When we reacquaint ourselves with Barnard's seminal ideas, we recognize that issues of leader authenticity are always salient it is just that we accentuate them during the times when major moral shocks occur in the corporate world.

In this paper, we examine the philosophical and psychological traditions in conceptualizing authenticity and explore how Barnard's classic works convey historical meanings of authentic executive leadership. To survey these traditions and interpret these meanings, we use a form of interpretative logic proposed by Bevir (1999) and apply it to tease out Barnard's key ideas of relevance for theorizing on authenticity of executive leadership. The approach is helpful in the identification of the conditions that contribute to myriad outcomes (e.g., failure, crisis, tragedy, and/or success) of executive authenticity in the leadership role.

Issues of executive authenticity are quite salient in the post-Enron times, just as they were salient to Barnard in the post-Depression era. By revisiting management classics (i.e., the classic works of our past) like Barnard's research and by exploring the cultural meanings of management phenomena, we strive to develop an alternative, post-hoc approach to inquiry of executive authenticity, which may facilitate new "possibilities of reinventing theory, reinterpreting evidence, and rediscovering voices and issues" (Kilduff \& Dougherty, 2000: 778). 


\section{Interpretative Logic of Deriving Historical Meanings from Management Classics}

Management phenomena may convey specific cultural meanings, as shown by the evolving research on management fads and fashions (Abrahamson, 1991). The only way to acquire knowledge of how management phenomena evolve as meaningful cultural phenomena is through analyzing historical works. In particular, the discipline of the history of ideas deals with studying cultural meanings from a historical perspective, as historians try to interpret cultural phenomena in terms of historical processes (Bevir, 2000).

Historians of ideas face the daunting challenge of determining what logic (i.e., forms of reasoning) is appropriate for studying the ideas/concepts of interest (e.g., authenticity of executive leadership). Bevir argues that an appropriate logic should be based on postanalytic philosophy, which is grounded in the Wittgensteinian assumption that we share a "grammar of our concepts" (i.e., a common web of beliefs derived from our shared traditions). This logic cannot yield a historical account (i.e., how a historian can uncover historical facts), but rather a normative account of reasoning (i.e., what we as historians do to winnow specific meanings). In turn, normative reasoning can provide us an appropriate rational justification to explain the meanings that we have uncovered.

By opposing both objectivism (i.e., modernist logic of discovery) and skepticism (i.e., post-modernist relativism and irrationalism), Bevir carves a middle-of-the-road path to connect shared traditions with the author's and readers' perspectives in the process of uncovering historical meanings. Specifically, he posits that individual viewpoints of the author and the readers consist of individual thoughts and beliefs that are embedded in the wider web of contemporary beliefs that evolved from traditions. By making connections between traditional and contemporary views, historians of ideas act as translators explaining the people of the past to us today using our own personal lens of discovery.

To support the ascription of meanings to a classic (i.e., certain beliefs to an author's work), historians of ideas should first examine the traditional and contemporary perspectives on the meanings of the concept explored from the classics. Next, historians should organize historical objects (e.g., citations) from the classics studied and relate them to each other, as well as to the traditional and contemporary perspectives, in order to weave many historical artifacts into a single tapestry. In this way, historians of ideas attempt to explain why the author held a specific belief not only by relating it to the author's other beliefs but also by embedding it in the conceptual network to which it belongs. Finally, historians of ideas should be aware that the threads of the tapestries of meanings that they weave out of historical objects are conditional, yet not arbitrary. These threads are not a part of the discovery tapestry, but could be valuable for researchers to weave/construct a post-hoc theory. In the following section, we will weave the threads of authenticity meanings from philosophical and psychological traditions.

\section{Historical Meanings of Authenticity}

The concept of authenticity gains prominence in times when individuals facing conflicting social pressures become entrapped in moral dilemmas that are engendered by the complex evolution of modern civilization (Cranton \& Carusetta, 2004). The times of evolving change require leaders with a stable philosophy of the self, as well as of others in the organization and community. In such turbulent times, leader authenticity becomes salient because the continuity of organizations as social systems is threatened by multiple discrepancies among leader responsibilities toward the self, toward the followers, and toward other stakeholders (Badaracco, 1992). Multiple meanings of authenticity and discrepancies in authenticity have been examined in history of philosophy and psychology.

Philosophical meanings of authenticity have been historically articulated in terms of individual virtues and ethical choices, while psychological meanings of authenticity have been historically articulated in term of individual traits/states and identities (See Table 1). In the following parts of this section, these varieties of authenticity meanings are addressed in detail. 
Table 1: Historical Meanings of Authenticity

\section{PHILOSOPHICAL MEANING}

i. Authenticity as Moral Virtue

- A moral response to declining civic and religious values (Baumaster, 1987).

- One's emotional orientation toward the world (Furtak, 2003: 424).

- The reflection of one's emotionally substantive way of living (Kierkegaard, 1996)

- Virtuous aspiration to rise above the 'average ness' of following someone else's directions or following the crowd (Pianalato, 2003).

\section{ii. Authenticity as Ethical Choices}

- Winning oneself" by making authentic, self-motivated choices Heidegger's (1962/1927).

- Recognition of one's psychological will and skill to balance private interest and public responsibility when choosing alternatives and setting goals (Sartre, 1948).

- Capacity of the individual to search for progressive ways of harmonizing the demands of personal self-development with those of public responsibility to develop such capacity in others (Adorno, 1953).

- Self as a difference between real and ideal mind and soul (Danzinger, 1997).

\section{PSYCHOLOGICAL MEANINGS}

\section{iii. Authenticity as Trait/State}

- Individual-difference psychological construct that reflects not only self-awareness of one's motives and unbiased self-relevant cognitions, but also self-determination of one's behavioral and relational choices (Kernis, 2003a).

- Expression of one's own convictions accompanied with the acceptance of responsibility for one's own decisions (Hoy et al., 1996).

- Individual state that occurs when individuals self-regulate in ways that satisfy their basic psychological needs for competence, self-determination, and relatedness (Ryan \& Deci, 2002).

- Conflicting feelings and goals that meaningfully promoting self-growth experiences and informing about the complexity of one's true feelings (Goldman \& Kernis, 2002: 5).

iv. Authenticity as Identity

- Meanings that we attach to our particular identities in self-referential terms Erickson (1995).

- Owning one's personal experiences" and acting in accord with "one's inner thoughts and feelings (Harter, 2002).

- Claim that is made by or for someone, thing, or performance and either accepted or rejected by relevant others (Peterson, 2005).

- Individual judgment of his or her social roles using the norms that others would use to judge him or her.

\section{Philosophical Meanings}

The philosophical importance of authenticity was first advocated by the Greek Stoics, as a moral response to declining civic and religious values (Baumeister, 1987). The medieval times emphasized the theological view of the self, grounding authenticity in conceptualization of differences between real and ideal mind and soul (Danzinger, 1997). It was only with the emergence of existential philosophy that the self was construed as a psychological entity, separate from the concepts of mind and soul (Harbus, 2002). 
The proximal foundation of the authenticity construct stems from Heidegger's (1962/1927) idea of "winning oneself" by making authentic, self-motivated choices. Heidegger argues that authenticity is particularly relevant in times of radical social change. In these situations, there is a temptation to live 'inauthentically' because change widens the moral gap between individual responsibility for freedom and autonomy and social responsibility to follow the shared norms of the community. This gap makes our daily routines appear empty and alienates us not only from others but also from the self.

Sartre (1948) criticized Heidegger's conceptualization of authenticity arguing that it was vague and open to negative politics of difference. In Sartre's view, the idea of authenticity is positive, as it implies recognition of one's psychological will and skill to balance private interest and public responsibility when choosing alternatives and setting goals. In addition, Adorno (1953) criticized Heidegger's conceptualization of authenticity as a moral "slippery slope" that may easily regress. In Adorno's view, authenticity implies the capacity of the individual to search for progressive ways of managiing the demands of personal selfdevelopment with the need to develop such capacity in others.

Kierkegaard was the first philosopher to blend the motivational and cognitive bases of authenticity with its emotional basis (Perkins, 1990). In the Kierkegaardian perspective, authenticity can be understood as "one's emotional orientation toward the world" (Furtak, 2003: 424), reflecting the condition of one's emotionally substantive way of living. The primary assumption of this perspective is that emotions, as intentional phenomena, are a part of one's reasoning (Nussbaum, 2001).

Specifically, Kierkegaard

conceptualized authentic emotional perception and response, positing that emotion/passions and cognition/beliefs are intertwined in our understanding of the world. When our emotional perceptions are coherent, our emotional response to objects, events and/or people is authentic. The absence of an authentic emotional response indicates that one has given in to some social sentiments at the expense of his/her genuine feelings (Kierkegaard, 1987: 124). Such a sentimentalist is either 'inauthentically' detached from his/her own true feelings or participates in the moral world on false terms.

When people are not aware of their emotional state, they become not only free from emotions but also empty of emotions. The lack of emotional self-awareness is likely to destabilize one's self-esteem and self-confidence and engender moral deterioration, paralysis, or disengagement (Diamond \& Allcorn, 1984). Devoid of affective bonds with the self, these individuals tend to act either indifferently (presuming they cannot influence anything) or as narcissist/perfectionists (presuming they cannot be influenced by anything). Their individual self-esteem becomes insecure because "the inauthentic person, who resists the virtues of consistency and commitment, will be incapable of future-oriented emotion for the same reason that $\mathrm{s} / \mathrm{he}$ cannot follow up on the ways s/he has been moved in the past" (Furtak, 2003: 433). These individuals are incapable of being truly responsible because they are unaware of their moral situation. Instead, they either avoid taking responsibility or take a selfserving view of responsibility. Due to an inauthentic orientation toward responsibility, these individuals cannot perform "any moral role that requires sustained care" (Furtak, 2003: 433). Therefore, the lack of emotional authenticity places a limit to their capacity to become authentic leaders.

Contemporary philosophers are more concerned with "ethics of authenticity" (Taylor, 1992). In this view, the concept of authenticity reflects one's genuine moral judgment about the value of the conflicting goals that are pursued individually and collectively (Ferrara, 1994). Since one's moral judgment often reflects a tension between one's personal norms of responsibility and the collective norms of moral conformity, authenticity can be viewed as an individual state-like trait that enables the individual to reconcile this tension. For instance, Pianalato (2003) suggests authenticity of an individual is a virtuous aspiration to rise above the average expectations of following someone else's directions or following the crowd. In other words, authentic individuals are virtuous due to their reluctance to rely on commonly accepted schema when seeking solutions to moral problems (Pianalato, 2003). This approach to authenticity is similar to that of 
Heidegger (1962/1927), except that Heidegger's arguments centered on how an individual acts, whereas Pianalato's arguments center on the underlying reasoning behind an individual's moral judgments.

\section{Psychological Meanings}

Psychological traditions of authenticity originate from humanistic approaches to personality psychology. For example, Erickson (1995) argues that we can tap into the authenticity construct more appropriately by viewing it through the meanings that we attach in self-referential terms to our particular identities. Authenticity, viewed as a commitment to self-referential meanings, implies "owning one's personal experiences" and acting in accord with "one's inner thoughts and feelings," as a way of resolving the tension/conflict between moral conviction and moral conformity (Harter, 2002: 382). An individual's authenticity is not simply a response to values expressed by others, but an expression of one's own convictions accompanied with the acceptance of responsibility for one's own decisions (Hoy et al., 1996).

Recently, Kernis (2003a) defined authenticity as an individual-difference psychological construct that reflects not only self-awareness of one's motives and unbiased self-relevant cognitions, but also selfdetermination of one's behavioral and relational choices. Addressing the authenticity of the individual and relational self, Goldman and Kernis (2002) operationalized the concept of psychological authenticity in terms of its cognitive (awareness, unbiased processing), behavioral (action), and social (relational orientation) aspects. The main assumption of the individual-differences view of authenticity is that authentic individuals will likely possess the capacity to develop more valuable and meaningful exchanges with both peers and followers.

Another contemporary perspective on authenticity emphasizes role identification (Guthey \& Jackson, 2005). In this perspective, authenticity is viewed as socially constructed rather than as a trait or state of an individual. Here, "authenticity is a claim that is made by or for someone, thing, or performance and either accepted or rejected by relevant others"
(Peterson, 2005: 1080). Therefore, authenticity can be represented as the process of fabricating authenticity that can vary from 'inauthenticity,' over pseudo-authenticity, to legitimate authenticity. As this outcome is an important element of one's social status, individuals will judge the authenticity of their social roles using the norms that others would use to judge them (Trilling, 1972).

\section{Meanings of Authenticity in Leadership Studies}

Philosophical meanings of authenticity were explored in leadership studies during the 1960 s, when an organization's authenticity was viewed as a manifestation of its leader's individual authenticity (Brumbaugh, 1971). In these studies, authenticity was described as a social condition of minimal discrepancy between projected external appearance and underlying internal structure (Etzioni, 1968). Specifically, Rome and Rome (1967: 185) argue: "A hierarchical organization, in short, like an individual person, is 'authentic' to the extent that, throughout its leadership, it accepts its finitude, uncertainty, and contingency; realizes its capacity for responsibility and choice; acknowledges guilt and errors; fulfills its creative managerial potential for flexible planning, growth, and charter or policy formation; and responsibly participates in the wider community." However, Halpin and Croft (1966) define organizational authenticity in terms of the openness of organizational climate, which reflects the extent to which individuals resist personal change when assuming professional and leadership roles. They argue that an open organizational climate is a reflection of cognitively open and reality centered authentic leaders. In open climates people are real, interactions are genuine, and behavior is self-regulated (Henderson \& Hoy, 1983). Similarly, Seeman (1960) posits that leaders are authentic to the extent they are able to reduce ambivalence about their leadership role, while Argyris (1957) claims that authentic leaders are aware not only of the organization's worth but also of their own self-worth and that of others.

Psychological meanings of authenticity in leadership studies were debated relative to authenticity (Bass and Steidlmeier, 1999) and 
pseudo-authenticity (Price, 2003) of transformational leaders. Recently, a growing interest of leadership researchers has focused on a developmental view of authentic leadership (Avolio, Luthans, Gardner, \& Walaumba., 2005). This view emphasizes a process that draws on positive organizational context and capacities and nurtures self-awareness and selfdetermination of leaders and followers to exhibit sustained positive behavior (May, Chan, Hedges \& Avolio, 2003).

\section{Leader Authenticity: Post-Hoc Theorizing on Barnard's Foundations}

In Barnard's works, the scope of authenticity meaning is narrowed to authenticity of executive leadership. Barnard (1948: 83) defines leadership as the "quality of the behavior of individuals whereby they guide people or their activities in organized effort." In accord with philosophical traditions of authenticity meanings, he recognized the need for leaders "who can both understand and excel at the practical elements of business while remaining introspective and thoughtful in their pursuit of moral excellence" (Ryan \& Scott, 1995: 457). Barnard refers to responsibility as the key quality required for executive leadership (Strother, 1976). In line with psychological traditions of authenticity meanings, Barnard (1948: 95) defines responsibility as an "emotional condition that gives an individual a sense of acute dissatisfaction because of failure to do what he feels is morally bound to do or because of doing what he thinks is morally bound not to do, in particular concrete situations."

Barnard focuses his attention primarily toward organizational leaders - executives whose authenticity is challenged by their responsibilities with respect to themselves, their followers, and the public (Barnard, 1948). In particular, he makes a distinction between two primary types of responsibility: personal responsibility and organizational (i.e., representative or corporate) responsibility. Personal responsibility refers to the character of individuals, which implies "avoidance of criminal acts, gross and public immoralities and in particular stealing and lying; a willingness to recognize the interests of others to the extent of ordinary courtesy; and finally, a willingness to discharge commitments, that is to perform duties accepted, to honor promises" (Barnard, 1958:6).

Organizational responsibility can be subdivided into internal (representative) and external (corporate) responsibility. Representative responsibility refers to acting in the official role "in accordance with the aims or goals or by methods determined by others" (Barnard, 1958:6). Corporate responsibility originates from the social invention of the limited liability corporation as an important factor in economic and social stability. Although "the corporation, as something having the attributes of a personality, is a legally authorized fiction ...there is imputed to it not only legally but popularly a special responsibility as if it were a person; hence there can be attributed to it moral and immoral action" (Barnard, 1958:7). "The responsibilities of corporations, aside from the obligation to conform to their charters and the law, are of two kinds: (1) those which may be called internal, relating to the equitable interests of shareholders, directors, officers, and employees; and (2) those relating to the interests of competitors, communities, government, and society in general" (Barnard, 1958:7). Barnard's point is that a persistent conflict can exist between personal and organizational responsibilities. This conflict reflects a moral tension engendered by the oftentimes competing interests of the executive, the organization, and the public (Novicevic, Hench \& Wren, 2002).

The meanings conveyed by Barnard's examination of the conflict inherent in executive responsibility, which resonate well with the philosophical and psychological meanings of the authenticity concept, provides a starting point for our theorizing about authenticity of executive leadership. Our rational derivation of hermeneutic meanings from Barnard's works is that authenticity of organizational leadership depends upon the leader success or the lack of success in attempts to resolve the challenges inherent to moral conflict of responsibility (personal vs. organizational).

Barnard (1939) posits that leaders are responsible when they manage to resolve successfully the moral tensions within and the moral conflict between personal and 
organizational codes of conduct. As Barnard (1938: 279) points out, "the distinguishing mark of executive responsibility is that it requires not merely conformance to a complex code of morals but also the creation of moral codes for others." Responsibility, as a quality of a leader relevant for authentic leadership, becomes particularly salient when personal and organizational codes "have substantially equal validity or power in the subject affected, and conflict of codes becomes a serious personal issue" (Barnard, 1938: 264).

Like Barnard, contemporary researchers posit that individuals often tend to act after reflecting on their conflicts of personal responsibility (Kernis, 2003a). From the theoretical perspective of self-determination, a relevant indicator of acting on one's true values is individual self-esteem (Deci \& Ryan, 1995), which is a "central component of individual's daily experience" (Kernis, 2003a: 1). As executives are concerned not only with their personal values but also with the values of the organization's internal and external stakeholders, the worth of their individual selves is often linked with the "experience of contingent regard by significant others" (Ryan \& Brown, 2003: 71). Executives, who tend to conform to certain external standards or attempt to meet unrealistic goals, often experience low self-esteem. In contrast, executives who have a non-contingent, secure self-esteem seldom consider their self-worth dependent only on the evaluation of their personal performance by others (Kernis, 2003b). Therefore, executives with secure self-esteem tend to assume personal responsibility by acting on personal values, while those with low self-esteem tend to avoid it.

Personal values of executives sometimes collide with the values of the organization (Ryan \& Brown, 2003). In this case, maintaining one's authenticity becomes difficult and dependent on the executive's ability to cope with the tensions between their organizational responsibility and their confidence, rather than anxiety (Kashdan, 2002). Specifically, the lack of confidence in organizational values may engender social anxiety as fear of social situations "in which there is a perceived probability of experiencing scrutiny or rejection" (Kashdan, 2002: 789). Executives that cope with the conflicts of responsibility with anxiety are likely not to exhibit authenticity in their behavior (Michie \& Grooty, 2005). In contrast, for confident executives, secure self-esteem is the foundation of authenticity exhibited in their individual behavior as leaders (Kernis, 2003b).

Our integration of meanings from Barnard's works with the philosophical and psychological views of the authenticity concept, as they apply to executive leadership, is summarized and shown in Figure 1. The extent to which a leader manages responsibly the conflict between the tensions of personal values (with stability of secure self-esteem; Kernis, 2003b) and the tensions of organizational values (with emotional confidence in coping with organizational demands; Kashdan, 2002) leads to the consequences represented within the four cells of the matrix shown in Figure 1: 1) leadership failure (inauthentic leadership characterized by moral deterioration of a resigned leader), 2) leadership crisis (pseudoauthentic leadership characterized by moral paralysis of a perfectionist leader), 3) leadership tragedy (pseudo-authentic leadership characterized by moral disengagement of a narcissistic leader), and/or 4) leadership success (authentic leadership characterized by moral creativity of an authentic leader) in aligning authentically personal moral convictions with the moral demands of organizational leadership.

\section{Failure of Executive Authenticity}

The failure of executive authenticity (i.e., executive 'inauthenticity') reflects the moral deterioration of executive leadership. Moral deterioration entails both frustration/indecisiveness and "diminution of the general sense of responsibility, manifest in the tendency to let decisions hinge on chance, external or irrelevant determinants, or incidental pressures" (Barnard, 1938: 271). Moral deterioration becomes visible as inauthentic behavior via deliberate withdrawal, accompanied by the "development of an ability to avoid conflicts, known as keeping out of trouble, avoiding temptation, or avoidance of responsibility" (Barnard, 1938: 278).

Moral deterioration is exhibited by indifferent and often resigned executives that are very hesitant to accept personal responsibility 
Figure 1: Authenticity Matrix of Executive Leadership

\section{Personal Responsibility}

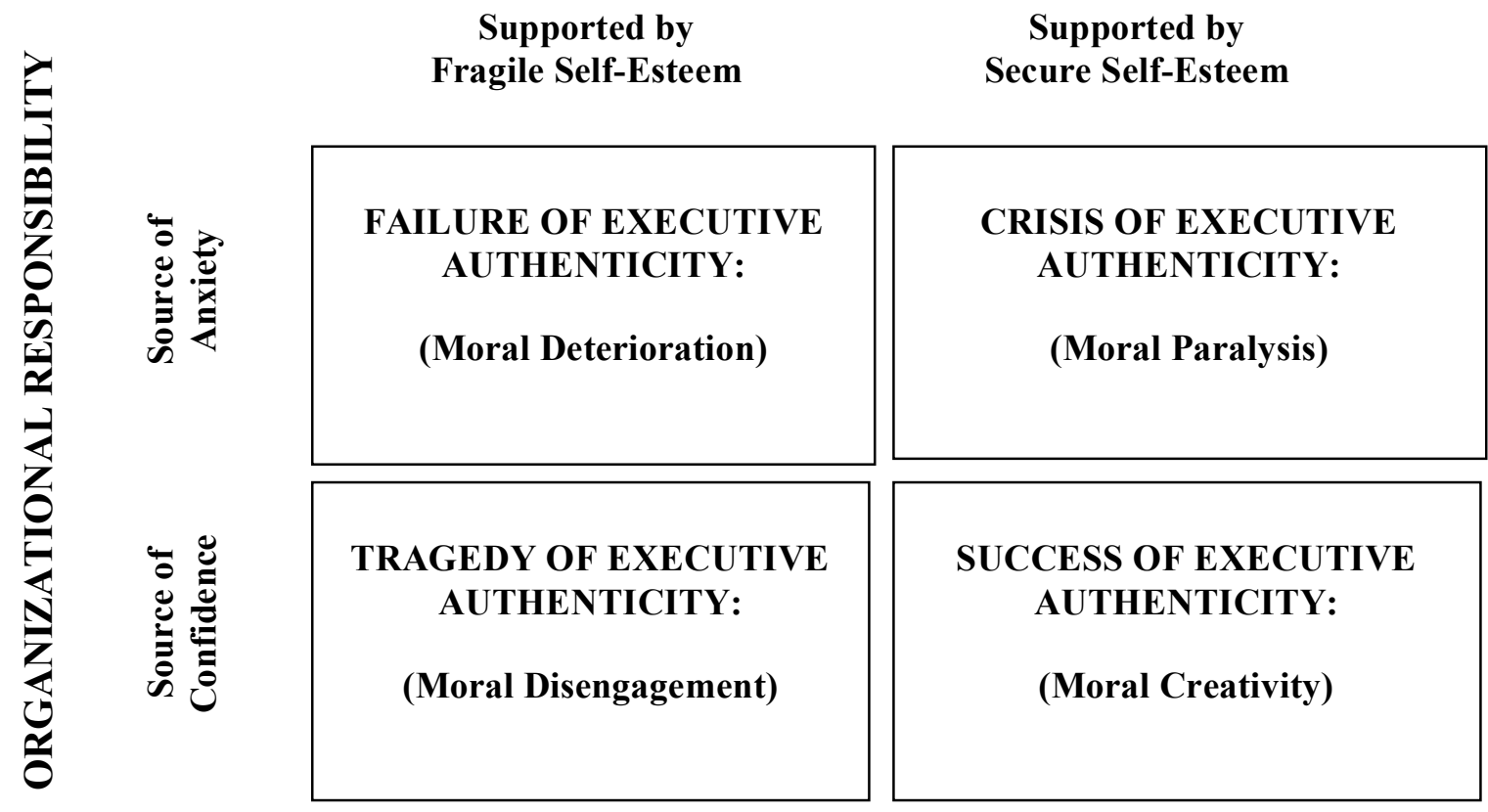

They may be secretive about their thoughts and feelings, trying to dissociate themselves from organizational reality (i.e., the 'out-oftouch' syndrome). Their focus on self-reliant roles with minimum responsibility (often deceiving and manipulating other managers to accept responsibility for them) (Michie \& Grooty, 2005) often leads to moral indecisiveness in accepting responsibility. Since they have difficulties in managing the tensions of their personal and organizational responsibilities, these executives survive only if their followers compensate for their deficiencies and take the blame for failures (Diamond \& Allcorn, 1984). Jacques Attali, the former president of the European Bank for Reconstruction and Development, is an example of a leader who was indifferent about pursuing personal or company responsibilities but rather promoted an irresponsible culture of extravagance. Having taken the leadership position without any prior banking or administrative experience, he spent twice as much on the headquarters remodeling than on loans to Eastern Europe.

\section{Crisis of Executive Authenticity}

The crisis of executive authenticity reflects moral paralysis of executive leadership. Moral paralysis of action is "accompanied by emotional tension, and ending in a sense of frustration, blockade, uncertainty, or loss in decisiveness and lack of confidence" (Barnard, 1938: 264). The personal codes are commonly dominant relative to the organizational codes with these individuals of "moral complexity in terms of the number of codes that govern their personal conduct," who do not possess "the capacity of responsibility" for the position of authority to which they are promoted (Barnard, 1938: 271). On the surface, these pseudoauthentic executives "though possessing quite complex moralities, are seldom plagued with conflicts because they are inactive" (Barnard, 1938: 271).

Moral paralysis is exhibited by perfectionist executives. These perfectionist leaders are 
typically "micromanagers" that that tend to ignore criticism and delegate responsibility hesitantly - often with many strings attached and little encouraging feedback. When their perfectionism is compounded by arrogance, these individuals may become insensitive and distrusting. They also frequently blame others for inaction in intimidating ways, while providing a narrow circle of trust around them that extends only to those who follow their ways unconditionally (Diamond \& Allcorn, 1984). Leona Helmsley was a perfectionist both in tax evasion and in petty tyranny toward her subordinates.

\section{Tragedy of Executive Authenticity}

The tragedy of executive authenticity reflects moral disengagement of executive leadership. Moral disengagement entails conformance to the organizational code and violation of the personal code, "resulting in a sense of guilt, discomfort, dissatisfaction, or a loss of self-respect" (Barnard, 1938: 264). To avoid such feelings, these individuals lead with denial, displacing their responsibility to others and justifying their pseudo-authentic behavior with excuses of embellished language emphasizing the primacy of "doing good for the organization" at any cost (Bandura, 1999).

Moral disengagement is exhibited by narcissistic executives who thrive on change because they can easily turn their anxiety into actions, albeit with moral disengagement. They tend to focus on personal prestige giving little credit to others. Perceiving their organizational self as supreme, they might suspend organizational prestige to preserve their perceived importance as a leader. Although energetic and equipped with multi-tasking abilities, these individuals are autocratic manipulators that seldom delegate, while always demanding admiration and submission from their followers (Diamond \& Allcorn, 1984). Robert Maxwell was a narcissistic leader whose moral disengagement in abuse of the company's $\$ 1.4$ billion pension fund led to the demise of Maxwell Communications Corporation.

\section{Success of Executive Authenticity}

The success of executive authenticity reflects moral creativity of executive leadership. Moral creativity involves finding "some substitute action which satisfied immediate desire or impulse of interest, or the dictates of one's code, and yet conforms to all of other codes" (Barnard, 1938: 264). Moral creativity of authentic leaders is commonly indicated by the following leader qualities: 1) transparent honesty/character; 2) moral courage; and 3) experience-informed intuition (Barnard, 1939). These qualities are situation-specific as they "depend for their meaning in the specific case upon the situation, not merely the individual, either as interpreted by the actor or leader or others, and his/her interpretation will often differ from the interpretation mode by different observers" (Barnard, 1948: 102, italics in the original).

Emphasizing these leader qualities indicates Barnard's implicit moral pragmatism - "that the nature of the virtues is determined by the practice of the virtues" (Scott \& Mitchell, 1989: 315). Some pragmatic readers of Barnard's works may infer that the authenticity of executive leadership comes from "the will of individual managers to control their personal conduct in conformance with their moral codes in order to be responsible to those who depend on them" (Scott \& Mitchell, 1989: 315). Some less pragmatic readers would posit that authenticity should be understood not only as an achievement of the will but rather also as a matter of emotional response (Furtak, 2003; Michie \& Grooty, 2005).

The capacity for moral creativity is a crucial quality of authentic leaders. Authentic executives, having a genuine sense of the self, are adaptive to situational and organizational demands, but do not sacrifice their personal moral code. Even when critical events occur, they retain self-confidence and the stability of their self-esteem. Authentic executives are effective coordinators who are willing to delegate. Although highly inspiring and cooperative in transferring duties, these leaders are very firm when it comes to their true moral convictions that they never compromise (Diamond \& Allcorn, 1984). Howard Schultz, of Starbucks, is an example of an authentic leader who balances personal and social responsibilities, while building a pool of leadership-ready individuals in his organization.

In summary, the matrix illustrated in Figure 1 depicts how the failure, crisis, tragedy, and/or 
success of executive authenticity may occur under external organizational and internal psychological constraints. The proponents of authentic leadership development model believe that the likelihood of success can be improved through appropriate design of succession planning and programs/practice of developing authentic leaders (Illies et al., 2005). The espoused purpose of such succession planning and development programs is to cultivate leaders with the capability to preserve personal authenticity under external and internal challenges, while exhibiting a dedication to developing authentic leadership capabilities in others (Avolio \& Gardner, 2005).

\section{Discussion and Conclusion}

In this paper, we have used a rational approach to reconstructing the authenticity concept and exploring its meanings from Barnard's works. We reflected on the philosophical and psychological traditions of the concept in the light of our contemporary understanding to "alter these traditions with our own reasoning" (Bevir, 1999: 225). In this way, we strived to discover "the newness of the past" using our logical reasoning as a method to interpret the authenticity concept (Anhkersmit, 2000). Derived from Barnard's works, authenticity reflects a leader's moral capacity to align responsibilities to the self, to the followers, and to the public in efforts to sustain cooperative efforts within and outside of the organization.

Our reflections on Barnard's foundations indicate the authenticity concept connotes specific perceived attributes of one's self when acting in different roles either as an isolated individual or as an organization/community member. These partially trait-like (i.e. stable) and partially state-like (i.e. malleable) attributes influence how executives respond cognitively and affectively toward acceptance of personal and social responsibilities in the organizational and community leadership roles.

Whether cognitive and emotional responses of executives to their environment are authentic, pseudo-authentic or inauthentic will be influenced by the extent to which executives are able to manage the tensions that occur within each of their responsibilities, as well as the conflict between their responsibilities. In other words, authenticity, pseudo-authenticity or 'inauthenticity' depicted in Figure 1 may seem like a social fact that is simultaneously a property of both executives as leaders and the setting in which they lead (Manning, 1997). For a stable authenticity of leaders, the harmonious functioning of their multiple responsibilities needs to be sustained. Only those executives who can master successfully these challenges of responsibility tensions and conflicts will exhibit authentic leadership. They may not only engender a spirit of self-regulated positive behavior and positive self-development in others in the organization, but also promote a transparent, trusting and open climate that supports constructive exchanges with stakeholders.

Future research should examine which underlying individual factors may contribute to the failure of leader authenticity (e.g.,, instability of leader virtues, ethical choices, self-esteem, or identity). Also, organization context (culture, climate and support) are likely factors of influence, just as social factors are (leader social identity, peer influence and./or followers' perceptions). A more ambitious empirical research program should investigate how different authentic leadership is from other constructs of leadership (transformational, charismatic or servant). These studies will require a dual pronged research approachrevisiting Barnard's work and conducting critical and rigorous empirical research-which wil serve to blend the wisdoms of Barnard with research technology and current wisdoms.

\section{References}

Abrahamson, E. 1991. Managerial fads and fashions: The diffusion and rejection of innovations. Academy of Management Review, 16: 586-612.

Adorno, T. E. 1973/1953. The jargon of authenticity, K. Tarkowski \& I. Will (Trans.), Evanston, IL: Northwestern University Press.

Ankersmit, F. 2000. Comments on Bevir's 'The logic of the history of ideas', Rethinking History, 4(3): 321-331.

Argyris, C. 1957. Personality and organization, New York: Harper \& Brothers. 
Avolio, B. \& Gardner, W. 2005. Authentic leadership development: Getting to the root of positive forms of leadership, Leadership Quarterly, 16 (3): 315-338.

Avolio, B. J., Gardner, W. L., Luthans, F., \& Walumbwa, F. O. 2005. Authentic leadership development: Building integration and differentiation. Leadership Quarterly, 16(3): 343-372.

Bandura, A. 1999. "Moral Disengagement in the Perpetration of Inhumanities, Personality and Social Psychology Review, 3(3): 193209.

Badaracco, J. 1992. Business ethics: Four spheres of executive responsibility, California Management Review, 34:3 (spring), 64-79.

Barnard, C. 1938. The functions of the executive. Cambridge, MA: Harvard University Press.

Barnard, Chester I. 1939. Dilemmas of leadership in the democratic process. Princeton University Press.

Barnard, C. 1948. Organization and management. Cambridge, MA: Harvard University Press.

Barnard, C. 1958. Elementary conditions of business morals, California Management Review, 1(1): 1-13.

Barnard, C. 1995. The significance of decisive behavior in social action: notes on the nature of decision, Journal of Management History, Vol. 1 No. 4, pp. 28-87.

Bass, B.M., and Steidlmeier, P., 1999. Ethics, character, and the authentic transformational leadership behavior, Leadership Quarterly, 10 (2):181-217.

Baumeister, R. 1987. How the self became a problem: A psychological review of historical research. Psychological Review, 52(1): 163-176.

Bennis, W. 2003. "Flight of the Phoenix: Authentic Leaders Learn How to Fly," Executive Excellence May 2003, 20(5): 45.

Berger, P. 1973. Sincerity and authenticity in modern society, Public Interest, 31: 81-89.

Bevir, M. 1999. The logic of the history of ideas, Cambridge, MA: Cambridge University Press.

Bevir, M. 2000. The logic of the history of ideas, Rethinking History, 4(3): 295-300.
Brumbaugh, R.B. 1971. "Authenticity and Theories of Administrative Behavior," Administrative Science Quarterly, 16(1): 108-112.

Clifton, D. O., \& Harter, J. K. 2003. Investing in strengths. In K. S. Cameron \& J. E. Dutton \& R. E. Quinn (Eds.), Positive organizational scholarship (pp. 111-121). San Francisco, CA: Berret-Koehler.

Conger, J. \& Fulmer, R. 2003. Developing your leadership pipeline, Harvard Business Review, 81(12): 76-84.

Cooper C., Scandura, T. \& Schriesheim, C. 2005. Looking forward but learning from the past: Potential challenges to developing authentic leadership theory and authentic leaders, Leadership Quarterly, 16(3): 475493.

Cranton, P. \& Carusetta, E. 2004. Developing authenticity as a transformative process, Journal of Transformative Education, 2(4): 276-293.

Danziger, K. 1997. The historical formation of selves. In R. Ashmore \& L. Jussim (Eds.), Self and identity: Fundamental issues: 137159. New York: Oxford University Press.

Deci, E. \& Ryan, R. 1995. Human autonomy: The basis fir true self-esteem. In M. Kernis (Ed.), Efficacy, agency, and self-esteem: 31-49. New York: Plenum.

Diamond, M. \& Allcorn, S. 1984. Psychological barriers to personal responsibility, Organizational Dynamics, 12(4): 66-77.

Dasborough, M. \& Ashkanasy, N. 2002. Emotion and attribution of intentionality in leader meber relationships, Leadership Quarterly, 13: 615-634.

Erickson, R. 1995. The importance of authenticity for self and society, Symbolic Interaction 18(2): 121-144.

Etzioni, A. 1968. Basic human needs, alienation and inauthenticity, American Sociological Review, 33: 870-885.

Ferrara, A. 1994. Authenticity and the project of modernity, European Journal of Philosophy, 2(3): 252-174.

Furtak, R. 2003. The virtues of authenticity: A Kierkegaardian essay in moral psychology, International Philosophical Quarterly, 43(4): 423-438.

Gardner, W. \& Schermerhorn, J. 2004. Unleashing individual potential: 
Performance gains through positive organizational behavior and authentic leadership, Organizational Dynamics, 33(3): 270-281.

George, B. 2003. Authentic leadership: Rediscovering secrets to creating lasting value, San Francisco, CAL Jossey-Bass.

Goldman, B.M. \& Kernis, M.H. 2002. "The Role of Authenticity in Healthy Psychological Functioning and Subjective Well-Being," Annals of the American Psychotherapy Association, 5: 18-20.

Guthey, E. \& Jackson, B. 2005. CEO portraits and the authenticity paradox. Journal of Management Studies, 42(5): 1057-1082.

Halpin, A. \& Croft, D. 1966. The organizational climate of schools. In A. Halpin (Ed.), Theory and research in administration; 131249. New York: Macmillan.

Harbus, A. 2002. The medieval concept of the self in Anglo-Saxon England, Self and Identity, 1: 77-97.

Harter, S. 2002. Authenticity. In C.R. Snyder \& S. Lopez (Eds.), Handbook of positive psychology: 382-394. London: Oxford University Press.

Heidegger, M. 1962/1927. Being and time, T. Macguire \& E. Robinson (Trans.), New York: Harper \& Row.

Hoy, W., Hoffman, J., Sabo, D. \& Bliss, J. 1996. The organizational climate of middle schools, Journal of Educational Administration, 34(1): 41-59.

Henderson, J. \& Hoy, W. 1983. Leader authenticity: the development and test of operational measure, Educational and Psychological Research, 3(2): 63-75.

Ilies, R., Morgeson, F, \& Nahrgang, J. 2005. Authentic leadership and eudemonic wellbeing: Understanding leader-follower outcomes, Leadership Quarterly, 16(3): 373-394.

Kashdan, T. (2002). Social anxiety dimensions, neuroticism and the contours of positive psychological functioning, Cognitive Therapy and Research, 26(6): 789-810.

Kernis, M. 2003a. Optimal self-esteem and authenticity: Separating fantasy from reality, Psychological Inquiry, 14(1): 83-89.

Kernis, M. 2003b. Toward a conceptualization of optimal self-esteem, Psychological Inquiry, 14(1): 1-26.
Kilduff, M. \& Dougherty, D. 2000. Change and development in a pluralistic world: the view from the classics. Academy of Management Review, 25(4): 777-782.

Kierkegaard, S. 1987. Either/Or, Princeton, NJ: Princeton University Press.Kierkegaard, S. 1996. Papers and journals, New York, Penguin.

Luthans, F. 2002. Positive organizational behavior: Developing and managing psychological strengths. Academy of Management Executive, 16(1), 57-75.

Luthans, F., \& Avolio, B. J. 2003. Authentic leadership development. In K. S. Cameron \& J. E. Dutton \& R. E. Quinn (Eds.), Positive organizational scholarship: Foundations of a new discipline (pp. 241258). San Francisco, CA: Berrett-Koehler.

Manning, K. (1997). Authenticity in constructivist inquiry: Methodological considerations without prescription. Qualitative Inquiry, 3(1), 93-115.

May D, Chan, A., Hodges, T. \& Avolio, B. 2003. Developing the moral component of authentic leadership, Organizational Dynamics, 32(3): 247-260.

Nussbaum, M. 2001. Upheavals of thought: the intelligence of emotions, Cambridge, MA: Cambridge University Press.

Novicevic, M., Hench, T. \& Wren, D. 2002. "Playing by ear"..."in an incessant din of reasons": Chester Barnard and the history of intuition in management thought, Management Decision, 40(10): 992-1002.

Perkins, R. 1990. Kierkegaard, a kind of epistemologist, History of European Ideas, 12: 7-18.

Peterson, R. 2005. In search of authenticity, Journal of Management Studies, 42(5): 1083-1098.

Pianalato, M. 2003. Resuscitation of a moral ideal. In Richard Lee (Ed.), Contemporary ethical theory: 218-230.

Price, T. 2003. The ethics of authentic transformational leadership, Leadership Quarterly, 14(1): 67-82.

Rome, B. \& Rome. S. 1967. Humanistic research on large social organizations. In J. Bugental (Ed.), Challenges of humanistic psychology: 181-193. New York: Mc Graw-Hill.

Ryan, L. \& Scott, W. 1995. Ethics and 
organizational reflection: The Rockefeller Foundation and postwar moral deficits 1942-1954, Academy of Management Review, 202(2): 438-461.

Ryan, R. \& Brown, K. 2003. Why we don't need self-esteem: Our fundamental needs, contingent love, and mindfulness, Psychological Inquiry, 14(1): 71-76.

Sartre, P. 1948. Anti-Semite and Jew. New York: Grove Press.

Seeman, M. 1960. Social status and leadership. Columbus: Ohio State University Press.

Seligman, M. E. P. 2002. Authentic happiness. New York, NY: Free Press.

Senge, P. 1999. The discipline of innovation, Executive Excellence, June: 10-11.

Shamir, B. \& Eilam, G.. 2005. "What's your story?" A life-stories approach to authentic leadership development, Leadership Quarterly, 16(3): 395-417.
Sparrowe, R. 2005. Authentic leadership and the narrative self, Leadership Quarterly, 16(3): 419-439.

Strother, G. 1976. The moral codes of executives, Academy of Management Review, 15: 13-22.

Taylor, C. 1992. The ethics of authenticity, Cambridge, MA: Harvard University Press.

Terry, R. W. 1993. Authentic leadership: Courage in action. San Francisco: Jossey Bass.

Trilling, L. 1972. Sincerity and authenticity, Cambridge, MA: Harvard Univ. Press.

Wolf, William B. 1973. Conversations with Chester I. Barnard. Cornell University: ILR Press. 